\section{SYNTHESIS OF THIOUREA DERIVATIVES FROM $M$-METHOXYCINNAMIC ACID AS ANTIANGIOGENIC CANDIDATE}

Juni Ekowatia*, Iwan Sahrial Hamidb, Kholis Amalia Nofiantia, Shigeru Sasakic

aFaculty of Pharmacy, Airlangga University, Surabaya, Indonesia bFaculty of Veterinary Medicine, Airlangga University, Surabaya, Indonesia

cInstitute Medicinal Chemistry, Hoshi University, Tokyo, Japan
Article history

Received

12 December 2018

Received in revised form

20 April 2019

Accepted

22 April 2019

Published online

25 June 2019

*Corresponding author juni-e@ff.unair.ac.id

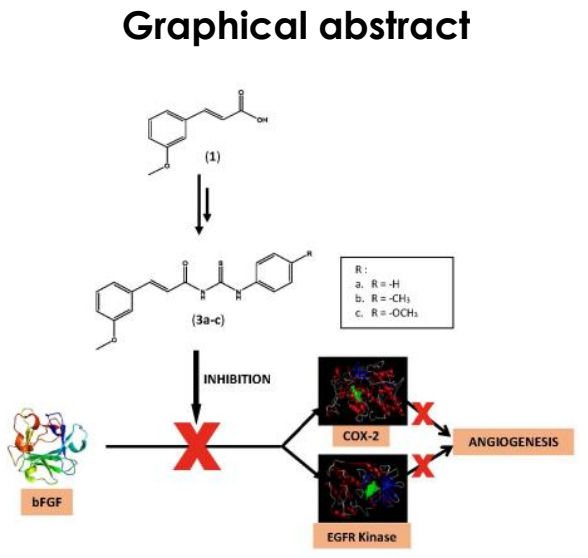

\begin{abstract}
Microwave-assisted nucleophilic acyl substitution was employed to obtain thiourea derivatives $(3 a, 3 b, 3 c)$ from $m$-methoxycinnamic acid (1). This synthesis method successfully yielded $60-70 \%$ reaction product. In vivo anti-angiogenic evaluation was conducted by chick chorioallantoic membrane model, by which each of the derivative at dose 30,60 , and $90 \mu \mathrm{g}$ induced by bFGF and compared to celecoxib $60 \mu \mathrm{g}$ as positive control. It was found that all of the synthesized compound at the tested dose were able to inhibit neovascularization and formation of endothelial cell of new blood vessels by $51-75 \%$. In silico analysis predicted that the anti-angiogenesis mechanism of all the synthesized compounds is through the inhibition of EGFR kinase and COX-2. N atom acts as hydrogen bonding acceptor by residue Gly526 of COX-2. While thiourea moieties of 3a-c have hydrophobic interaction by residues Ser530, Tyr385, and Leu352. In addition, the carbonyl group of thiourea of compound 3a-c inhibit EGFR kinase through the interaction with lys745. The pKCSM data revealed that $3 a-c$ absorbed in intestine by $89-92 \%$, and acut toxicity in rat category 4 , suggesting that the compounds show good absorption, and low toxicity. In conclusion, this study successfully synthesized thiourea derivatives, which have anti-angiogenesis activity, tested by CAM model.
\end{abstract}

Keywords: Microwave irradiation, angiogenic inhibitor, COX-2, EGFR, celecoxib, ADMET profile

(c) 2019 Penerbit UTM Press. All rights reserved

\subsection{INTRODUCTION}

Researchers reported that angiogenesis was one of the most contributing factor to the progressive growth of neoplasms and metastases which led to the death of cancer patients. It is a fundamental process of forming new blood vessels as an extension of the existed vasculature. This process is a critical step in tumor progression to supply oxygen and nutrition, by which, the cell proliferation and metastases occur [1,2].
Cyclooxygenase-2 (COX-2) catalyzes the conversion of arachidonic acid into PGE2 prostaglandins, which result in angiogenesis [3, 4]. Therefore, the inhibition of COX-2 pathway through binding with EP4 receptor will also restrain the angiogenesis $[5,6]$.

There have been many anti-angiogenesis inventions, including US Patent No. US8,778,340 B2; about anti-angiogenesis therapy for ovarian cancer, the drug bevacizumab, an anti-VEGF antibody [7]. Bevacizumab combined with other chemotherapy is proven efficacious for cancer 
patients. Unfortunately, bevacizumab also causes thromboembolic disorders, fatigue, intracranial hemorrhage, proteinuria, hypertension, and bowel perforation. [3, 8, 9].

Over the past few decades, vascular endhotelial growth factor (VEGF) signaling has been identified as a central axis in tumor angiogenesis [10]. One of the anti-angiogenesis therapies is tamoxifen sunitinib, which target on VEGF signaling pathway and kinase (11). On the other hand, long-term use of tamoxifen as chemotherapy, actually increases the VEGF levels in patients and stimulate the formation of new blood vessels that trigger metastases [12].

Celecoxib (CXB), a selective COX-2 inhibitor, suppresses VEGF gene expression by targeting the VEGF promoter. However, the use of celecoxib, also poses severe side effects, especially for patients with heart diseases $[6,12,13]$. Those fact show that there is a need to develop an alternative anti-angiogenesis agent as a strategic step in cancer treatment.

Some cinnamic derivatives, such as ethyl pmethoxycinamate, is reported for its activity to inhibit cancer growth, COX-2 production and angiogenesis [14-16]. Research also reveals that ferulic acid, (4-hydroxy-3-methoxycinnamic acid) and $p$-methoxycinnamic acid were able to inhibit COX-2 and cancer growth [17-19]. However, up this date, there is no report that explore the potency of its isomer, $m$-methoxycinnamic acid, or (E) -3- (3-methoxyphenyl)prop-2-enoic acid (1) and the derivatives, related to their activity on COX-1/2 and angiogenesis. In our previous study (data not shown), ferulic acid, which has a methoxy group at the meta position show analgesic activity and inhibition of COX-1/2.

The thiourea derivatives of $p$-methoxycinnamic acid are reported as chemopreventive agents that were able to restrain the fibrosarcoma growth in mice induced by benzopyrene [20]. Thiourea derivatives has analgesic activity by inhibiting COX-1/2 [21,22]. Gorab et al. (2017) also described that thiourea derivatives which have the sulphonamide groups can inhibit cancer through COX-2 barriers. Thiourea moiety has a hydrophobic interaction with COX-2 amino acid residues [22]. Therefore, this study aims modify the structure of compound 1 to thiourea derivatives and evaluate their activity to inhibit the angiogenesis COX-2 activity.

Over the past few years, innovative and important developments have taken place in microwave (MW) assisted synthesis methods. The use of single mode MW reactors, especially in continuous flow reactions, shows satisfactory results. This method provides several advantages such as the use of microwaves as an energy source to increase temperatures quickly because all samples are heated together so that synthesis time is more efficient and reaction products increase. Therefore, the thiourea derivatives of 1 was synthesized using microwave irradiation as an effort to implement green chemistry [24].

Molecular docking is one of the most common methodologies used in the discovery of novel small-molecule inhibitors. This computational technology is very helpful for the medicinal chemists in identifying the inhibitor of the biomolecular targets. This approach allows us to predict the interaction between the inhibitor and the residues $[14,16,25]$.

Prabhu et al. (2014) reported that the new VEGF inhibitors showed the hydrogen bonding between hydroxyl groups in some of the ligand with negatively charged of residue Asp 1046. The ligand also formed a cation-m interaction of the amino acid and the aromatic rings of the ligand. Besides that, the hydrophobic interaction also found in the residues of Ala866, Phe1047, Cys919, Phe918, Val848, and Cys1045. The nitrogen containing six-membered ring in the ligand performed a hydrophobic interactions of the residues Leu889, Ala866 [25].

Coskun et al. (2018) also reported the use of molecular docking experiment to analyze the potency of diflunisal derivatives as anti-cancer through the inhibition of COX enzyme. The results were compared to the in vitro assay [26].

So, in our present study, we intend to synthesize thiourea derivatives of $m$-methoxycinnamic acid using microwave irradiation, to analyze the activity using CAM model and to predict the inhibition mechanism by molecular docking study.

\subsection{METHODOLOGY}

\subsection{Materials}

m-Methoxycinnamic acid was obtained from Tokyo Chemical Industry Co., Ltd., Japan. Other used materials, i.e. aniline, p-tolvidine, p-anisidine, and all solvents in p.a. grade were obtained from E-Merck, Germany. bFGF was taken from Sigma Aldrich, Germany.

\subsection{Synthesis Derivates Thiourea of $m$ - methyoxycinnamic Acid}

Into a solution of $15 \mathrm{mmol} m$-methoxycinamic acid in $15 \mathrm{ml}$ benzene, 1 drop of pyridine and 2.4 eq thionyl chloride were added, then refluxed overnight. After that, excess of thionyl chloride and benzene are removed by rotary evaporation. The addition of benzene was repeated and removed again so that m-methoxycinamoyl chloride was produced, and was stored under Nitrogen condiition. Afterward, the solution of 7.5 mmol m-methoxycinamoyl chloride in $5 \mathrm{ml}$ dichloromethane was reacted with $10 \mathrm{mmol}$ ammonium thiocyanate and catalyzed by one 
drop of PEG 400. The mixture was irradiated by microwave at $132 \mathrm{~W}$ for approximately 30 seconds. The irradiation was repeated 3 times. Next, $7.5 \mathrm{mmol}$ aniline was put into the mixture, and then irradiated again for $4 \times 30$ seconds. After that, $2 \mathrm{~N} \mathrm{HCl}$ solution was added into the mixture to remove the pyridine. The crude product was neutralized by $10 \% \mathrm{NaHCO}_{3}$ solution, and then washed by distilled water. The precipitate was filtered and recrystallized by a mixture of dichloromethane-ethanol (1-1). This procedure was used for other aromatic amines (i.e $p$ tolvidine and p-anisidine).

\subsection{Physicochemical Study}

The physicochemical study of thiourea derivatives was conducted through Chem Draw Professional 15.0 program and pkCSM tool on line.

\subsection{Antiangiogenesis Study}

The embryonated chicken eggs in nine-day-old, obtained from PUSVETMA Surabaya, were incubated at $37^{\circ} \mathrm{C}$ and $60-70 \%$ humidity for one day. New vascular induction was performed using bFGF $60 \mathrm{ng}$ which was dissolved in $60 \mathrm{~mL}$ of rh of bFGF at a concentration of $1 \mathrm{ng} / \mathrm{mL}$ of Tris $\mathrm{HCl}$ under aseptic conditions. The test doses were 30, 60 and $90 \mu \mathrm{g}$. Compared to celecoxib at $60 \mu \mathrm{g}$ dose as positive control. The eggs were divided into eleven groups, each group contained five eggs. the first to third group were treated by compound $3 a$, fourth to sixth group were given compound $3 \mathrm{~b}$, seventh to ninth group were undertaken compound $3 c$, the tenth group was treated with celecoxib $60 \mu \mathrm{g}$, and the eleventh group was a negative control group, without any treatment except induction with bFGF. After 1 day of incubation, a $1 \mathrm{~cm}^{2}$ hole in the top of the egg was formed and air was released from the air chamber. Samples were dropped onto the paper disk, and impregnated into chorioallantoic membrane (CAM) of each chicken embryo. The hole in the egg was closed again and the egg was returned into the incubator until the 11 th day of the chicken embryo development. After that, the shell was opened, CAM was taken from the shell, then sliced for histological examination and staining by Hematoxylin and Eosin (HE). The formation of endothelial cells in neovascular capillaries was observed in the CAM cross section using a reverse $\mathrm{H} 600 \mathrm{~L}$ contrast phase microscope. The number of endothelial cells was determined in five visual fields of each slide at 400x magnification and compared to the positive and negative controls for subsequent analysis [14]. Statistical analysis between treatment and control groups was tested by one way ANOVA, followed by LSD test. The difference was considered significant at $\mathrm{p}<0.05$.

\subsection{Docking Study}

The molecular docking study of AMMS derivative, celecoxib and ligand reference FMM_91 [A] (lapatinib tosylate) into the three-dimensional structure of tyrosine kinase was performed using version 5.5 of the Molegro Virtual Docker (MVD) software. The structure of tyrosine kinase receptor was obtained from the Protein Data Bank (PDB IXKK ). Ligand preparation was carried out using ChemBio Ultra version 10.0 software; geometry optimized using MMFF 94 method and saved in Sybyl Mol2 format. All ligands were placed into the 1XKK (cavity-1) binding site parallel to the FMM_91 [A] ligand reference and 10 independent runs were carried out. The interactions between ligands and enzymes (docking scores) were predicted through the rerank score (RS). A lower negative score ( $\mathrm{kcal} / \mathrm{mol}$ ) indicated a stronger ligand enzyme bond. Validation of the docking study was carried out by FMM_91 [A] redocking to port 1 of 1XKK. The best docking results could be observed visually by comparing the molecular structure of the test with the FMM_91 [A] crystal structure to the active site [14].

\subsection{RESULTS AND DISCUSSION}

\subsection{Synthesis Derivates Thiourea of $m$ - methyoxycinnamic Acid}

The reaction scheme of synthesis thiourea derivatives using microwave irradiation as a source of energy is shown in Figure 1.

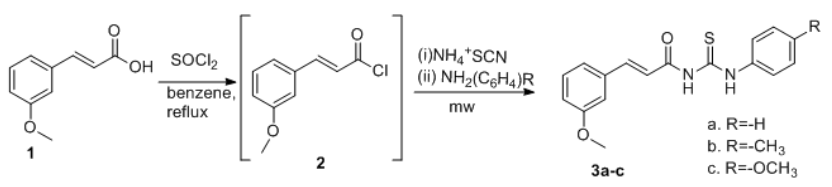

Figure 1 Synthesis route of thiourea derivatives of 1

(3a): (2E)-3-(3-Methoxyphenyl)-N-(phenylcarbamo thioyl)acrylamide

yellow needle crystal, MP: $174-175^{\circ} \mathrm{C}$. Rf: 0.7 (E†Acn-Hexane, 1:1). IR ( $\left.\mathrm{KBr} ; \mathrm{Cm}^{-1}\right): 3463(-\mathrm{N}-\mathrm{H}$, amide, $\left.2^{\circ}\right)$; 3223(-N-H, amine, $\left.2^{\circ}\right)$; 3031 (Csp $\left.{ }^{2}-\mathrm{H}\right)$; $1673(-$ $\mathrm{C}=\mathrm{O})$; 1598(-C=C-, alkene); $1547(-\mathrm{C}=\mathrm{S})$; 1168 (-C$\mathrm{O}-\mathrm{C}) ; 749$ (aromatic ring metha- substituted). UV/Vis $\lambda_{\max }(\mathrm{E \dagger OH}) \mathrm{nm}(\log \varepsilon): 302$. 'H NMR (400 $\left.\mathrm{MHz}, \mathrm{CDCl}_{3}\right): 3.75(3 \mathrm{H}, \mathrm{s}), 6.65(1 \mathrm{H}, \mathrm{d}, J=16 \mathrm{~Hz})$, $6.97(1 \mathrm{H}, \mathrm{dd}, 8 \mathrm{~Hz}, 2 \mathrm{~Hz}), 7.06(1 \mathrm{H}, \mathrm{t}, \mathrm{J}=2 \mathrm{~Hz}), 7.11$ $(1 \mathrm{H}, \mathrm{d}, J=7.6 \mathrm{~Hz}), 7.26-7.31(2 \mathrm{H}, \mathrm{m}), 7.40(2 \mathrm{H}, \mathrm{t}, J$ $=8 \mathrm{~Hz}), 7.66(2 \mathrm{H}, \mathrm{d}, J=7.6 \mathrm{~Hz}), 7.78(2 \mathrm{H}, \mathrm{d}, J=16 \mathrm{~Hz})$, $9.97(1 \mathrm{H}, \mathrm{s}), 12.66(1 \mathrm{H}, \mathrm{s}) .{ }^{13} \mathrm{C}$ NMR $\left(100 \mathrm{MHZ}, \mathrm{CDCl}_{3}\right)$ $\delta: 55.42$ (1C), 112.79 (1C), 117.55 (1C), 118.70 (1C), 121.61 (1C), 124.49 (1C), 127.04 (2C), 129.95 (2C), 
$130.18(1 \mathrm{C}), 135.12(1 \mathrm{C}), 137.64(1 \mathrm{C}), 146.60$ (1C). 160.04 (1C), 166.08 (1C), 178.93 (1C). MS (ESIHRMS), $[\mathrm{M}+\mathrm{Na}]^{+}: \mathrm{m} / \mathrm{z}(\%)=335.08$. Products yield: $60 \%$.

(3b): (2E)-3-(3-methoxyphenyl)-N-(4-methylphenyl carbamothioyl)acryl amide

Pale yellow crystal, MP: 202-203ㅇ. Rf: 0.8 (EłAc-nHexane, 1:1). IR $(\mathrm{KBr})$ : $3478\left(-\mathrm{N}-\mathrm{H}\right.$, amide, $\left.2^{\circ}\right)$; $3194\left(-\mathrm{N}-\mathrm{H}\right.$, amine, $\left.2^{\circ}\right)$; $3009\left(\mathrm{Csp}^{2}-\mathrm{H}\right) ; 1677(-\mathrm{C}=\mathrm{O})$; $1597(-\mathrm{C}=\mathrm{C}-$, alkene); 1538(-C=S); 1156 (-C-O-C); 779 (aromatic ring metha- substituted). UV/Vis $\lambda_{\max }$ (E†OH) nm (log $\varepsilon):$ 302. ${ }^{1} \mathrm{H}$ NMR $\left(400 \mathrm{MHZ}, \mathrm{CDCl}_{3}\right)$ $2.33(3 \mathrm{H}, \mathrm{s}), 3.82(3 \mathrm{H}, \mathrm{s}), 6.54(1 \mathrm{H}, \mathrm{d}, J=15.6 \mathrm{~Hz})$, $6.97(1 \mathrm{H}, \mathrm{dd}, J=8 \mathrm{~Hz}, 2.4 \mathrm{~Hz}), 7.06(1 \mathrm{H}, \mathrm{t}, J=2.4 \mathrm{~Hz})$, $7.19(2 \mathrm{H}, \mathrm{d}, J=8 \mathrm{~Hz}), 7.30(1 \mathrm{H}, \mathrm{t}, J=8 \mathrm{~Hz}), 7.53(2 \mathrm{H}$, $\mathrm{d}, J=8.4 \mathrm{~Hz}), 7.77(2 \mathrm{H}, \mathrm{d}, J=15.6), 9.18(1 \mathrm{H}, \mathrm{s})$, $12.48(1 \mathrm{H}, \mathrm{s}) .{ }^{13} \mathrm{C}$ NMR $\left(100 \mathrm{MHz} \mathrm{CDCl}_{3}\right): 21.12(1 \mathrm{C})$, 55.40 (1C), 113.07 (1C), 117.38 (1C), 118.86 (1C), $121.45(2 \mathrm{C}), 124.30(2 \mathrm{C}), 129.50(2 \mathrm{C}), 130.12(1 \mathrm{C})$, 135.19 (1C), 136.84 (1C), 146.40 (1C), 160.15 (1C), $165.82(1 \mathrm{C}), 178.81$ (1C). MS (ESI-HRMS) [M+Na] ${ }^{+}$: $\mathrm{m} / \mathrm{z}(\%)=349.0981(100)$. Products yield $: 70 \%$.

(3c): $\quad$ (2E)-3-(3-methoxyphenyl)-N-(4methoxyphenyl carbamothioyl) acrylamide Pale yellow crystal, MP: 168-169 $\mathrm{C}$. Rf: 0.7 (E†AC-nHexane, 1:1). IR (KBr): $3478\left(-\mathrm{N}-\mathrm{H}\right.$, amide, $\left.2^{\circ}\right)$; $3168\left(-\mathrm{N}-\mathrm{H}\right.$, amine, $\left.2^{\circ}\right)$; $3037\left(\mathrm{Csp}^{2}-\mathrm{H}\right) ; 1670(-\mathrm{C}=\mathrm{O})$; 1595(-C=C-, alkene); $1547(-\mathrm{C}=\mathrm{S}) ; 1173$ (-C-O-C); 776 (aromatic ring metha- substituted). UV/Vis $\lambda_{\max }$ (E†OH) nm (log $\varepsilon): 300 .{ }^{1} \mathrm{H}$ NMR $\left(400 \mathrm{MHz}, \mathrm{CDCl}_{3}\right)$ : $3.76(3 \mathrm{H}, s), 3.81(3 \mathrm{H}, \mathrm{s}), 6.64(1 \mathrm{H}, \mathrm{d}, J=15.6 \mathrm{~Hz})$, $6.91(1 \mathrm{H}, \mathrm{d}, J=8 \mathrm{~Hz}), 7.05(1 \mathrm{H}, \mathrm{t}, J=2.4 \mathrm{~Hz}), 7.29(2 \mathrm{H}$, $\mathrm{t}, J=8 \mathrm{~Hz}), 7.30(2 \mathrm{H}, \mathrm{t}, J=8 \mathrm{~Hz}), 7.51(2 \mathrm{H}, \mathrm{d}, J=2 \mathrm{~Hz})$, $7.77(1 \mathrm{H}, \mathrm{d}, J=15.6), 9.65(1 \mathrm{H}, \mathrm{s}), 12.41(1 \mathrm{H}, \mathrm{s}) .{ }^{13} \mathrm{C}$ NMR (100 MHz CDCl $): 55.40$ (1C), 55.60 (1C), 112.81 (1C), $114.14(2 \mathrm{C}), 117.48$ (1C), 118.80 (1C), $121.60(2 \mathrm{C}), 126.17$ (1C), 130.16 (1C), 130.60 (1C), 135.14 (1C), 146.42 (1C), 158.35 (1C), 160 (1C), 166.06 (1C), 179.19 (1C). MS (ESI-HRMS) [M+Na] ${ }^{+}$: $\mathrm{m} / \mathrm{z}(\%)=365.0931(100)$. Products yield $: 70 \%$.

The modification structure of compound 1 into $3 a$ showed the addition of seven carbons, six protons, two nitrogen and one sulfur in (Figure 1). It was marked by the loss of the widening and upward peaks in IR spectra due to the presence of intermolecular hydrogen bonds of carboxylic acid groups of compound 1 into thiocarbamothioyl groups in the form of a band at the wave number $3463\left(-\mathrm{N}-\mathrm{H}\right.$, primer, $\left.1^{\circ}\right)$ and $3223\left(-\mathrm{N}-\mathrm{H}\right.$, amine, $\left.2^{\circ}\right)$ on compound of $3 \mathrm{a}$.

The 'H-NMR (400MHz; $\left.\mathrm{CDCl}_{3} ; \mathrm{TMS}\right)$ spectra showed that there are sixteen protons in ten different signals. ${ }^{13} \mathrm{C}-\mathrm{NMR}(100 \mathrm{MHz} ; \mathrm{CDCl} 3$; TMS) revealed seventeen carbons. Nine aromatic protons were confirmed by 'H-NMR spectra in the chemical shift $(\delta \mathrm{H})$ respectively $6,97(1 \mathrm{H}, \mathrm{d}, J=2.2$ $\mathrm{Hz}), 7.06 \mathrm{ppm}(1 \mathrm{H}, \mathrm{d}, J=2.2 \mathrm{~Hz}), 7.11(1 \mathrm{H}, \mathrm{d}, J=7.6$ $\mathrm{Hz}), 7.26-7.31(2 \mathrm{H}, \mathrm{m}), 7.40(2 \mathrm{H}, \mathrm{t}, J=8 \mathrm{~Hz}), 7.66$
$(2 \mathrm{H}, \mathrm{d}, J=7.6 \mathrm{~Hz})$. Two aromatics of $3 \mathrm{a}$ also confirmed by chemical shift ( $\delta \mathrm{c}): 112.8$ (C2), 117.6 (C6), 121.6 (C4), 129.9 (C3/C5), 160.0 (C1) ppm. The second aromatic showed by $\delta_{c}=118.7$ (C2'), 124.5 (C6'), 127.0 (C3'/C5'), 130.2 (C1'), 135.1 (C4') ppm. Addition of aromatic group shift the $\lambda_{\max }$ to the higher wave number. This is due to bathochromic shift, the longer conjugated double bond, the easier electron excitation from $\pi$ to $\pi *$ orbital (Pavia et al., 2009). Absorption band at wave number $1673 \mathrm{~cm}^{-1}$ and carbon chemical shift $\delta c=166.1 \mathrm{ppm}$ showed the $-\mathrm{C}=\mathrm{O}$ amide. Thiocarbonyl $(-C=S)$ observed from wave number of $1547 \mathrm{~cm}^{-1}$, and $\delta c=178.9 \mathrm{ppm}$. The methoxy substituent was confirmed by singlet signal $(3 \mathrm{H})$ at $\delta H=3.75 \mathrm{ppm}$ and $\delta c=55.4 \mathrm{ppm}$. IR spectra on the wave number of $1168 \mathrm{~cm}^{-1}$ sugested the $-\mathrm{C}-\mathrm{O}-\mathrm{CH}_{3}$ bond. Alkene double bond was showed by two sinal on $\delta \mathrm{H}=6.65(1 \mathrm{H}, \mathrm{d}$, $J=16 \mathrm{~Hz})$ and $7.78(2 \mathrm{H}, \mathrm{d}, J=16 \mathrm{~Hz})$, revealing that the alkene was trans isomer. The carbon atom of alkene was also confirmed by $\delta c=137.6$ and 146.6 ppm. Based on ESI-HRMS [M+Na] ${ }^{+}$data, the found molecule mass of $3 a$ was $335.0824(\mathrm{~m} / \mathrm{z})$. This result is in accordance with molecular formula $\mathrm{C}_{17} \mathrm{H}_{16} \mathrm{~N}_{2} \mathrm{O}_{2} \mathrm{Sna}$ and the teoretical mass was 335.0825.

The changing of carboxylate group of 1 into thiocarbamothioyl of $3 \mathrm{~b}$, was suggested by IR absorption $\left(\mathrm{KBr}, \mathrm{cm}^{-1}\right)$ band on the wave number of $3478\left(-\mathrm{N}-\mathrm{H}\right.$, amide, $\left.2^{\circ}\right)$ and $3194(-\mathrm{N}-\mathrm{H}$, amine, $\left.2^{\circ}\right)$. The presence of this group was also supported by ${ }^{1} \mathrm{H}-\mathrm{NMR}\left(400 \mathrm{MHz}, \mathrm{CDCl}_{3}\right)$ spectra at $\delta_{\mathrm{H}}=9.18$ $\mathrm{ppm}(1 \mathrm{H}, \mathrm{s})$ for $-\mathrm{NHC}=\mathrm{O}$ and $12.48 \mathrm{ppm}(1 \mathrm{H}, \mathrm{s})$ for $-\mathrm{NHC}=\mathrm{S}$. The carbon atom of $-\mathrm{C}=\mathrm{O}$ and $-\mathrm{C}=\mathrm{S}$ was confirmed by $\delta c=165.82$ and $178.81 \mathrm{ppm}$. Whereas the IR spectra showed both functional group of absorption band on the wave number at $1677(-\mathrm{C}=\mathrm{O})$ and $1538(-\mathrm{C}=\mathrm{S}) \mathrm{cm}^{-1}$.

The addition of four proton of aromatic group was observed from two doublet symmetric signal on $7.53(2 \mathrm{H}, \mathrm{d}, J=8.4 \mathrm{~Hz})$ and $7.19(2 \mathrm{H}, \mathrm{d}, J=8 \mathrm{~Hz})$ which accordance with $\mathrm{AA}^{\prime} \mathrm{BB}^{\prime}$ aromatic system. The second aromatic group was confirmed by NMR profile at $\delta_{H}=6.97(1 \mathrm{H}, \mathrm{dd}, J=8 \mathrm{~Hz}, 2.4 \mathrm{~Hz})$, $7.06(1 \mathrm{H}, \mathrm{t}, J=2.4 \mathrm{~Hz}), 7.12(1 \mathrm{H}, \mathrm{d}, J=7.60 \mathrm{~Hz}), 7.30$ $(1 \mathrm{H}, \mathrm{t}, J=8.0 \mathrm{~Hz})$. Furthermore, the aromatic carbon atom was also suggested by twelve signals from $\delta c=113.1(C 2), 117.4(C 6), 118.8(C 4)$, 129.50 (C3/C5), 160.2 (C1), 118.9 (C2'), 121.5 (C6'), 124.30 (C3'/C5'), 130.1 (C1'), 135.2 (C4'). The double bond of alkene (-C=C-), was revealed by IR band absorption at wave number $1597 \mathrm{~cm}^{-1}$, accordance with that, the alkene proton was showed by $\delta_{H}=6.54(1 \mathrm{H}, \mathrm{d}, J=15.4 \mathrm{~Hz})$ and 7.77 $(2 \mathrm{H}, \mathrm{d}, J=15.4 \mathrm{~Hz})$, suggesting trans isomer. The carbon of alkene was confirmed by $\delta c=136.8$ and $146.4 \mathrm{ppm}$. The proton of methoxy group was observed as single peak $(3 \mathrm{H})$ on $\delta H=3.82 \mathrm{ppm}$, and the carbon atom on $\delta c=55.4 \mathrm{ppm}$. The $I R$ spectra gave absorption band on the wave 
number of $1156 \mathrm{~cm}^{-1}$ for ether of $3 \mathrm{~b}$. The proton and carbon atom of methyl group of $3 \mathrm{~b}$ was revealed by $\delta_{H}=2.36(3 \mathrm{H}, \mathrm{s}) \mathrm{ppm}$ and $\delta \mathrm{c}=21.1$ ppm. Finally, mass spectroscopy data (ESI-HRMS) found the molecular mass of $3 b[\mathrm{M}+\mathrm{Na}]^{+}$was 349.0981 (m/z). Molecular formula $\mathrm{C}_{18} \mathrm{H}_{18} \mathrm{~N}_{2} \mathrm{O}_{2} \mathrm{SNa}$. Teoretical mass $=349.0981$. When compared to compound $3 a$, there was an additional molecular weight of 14, which came from one carbon and two hydrogen.

Similar to $3 a$ and $3 b$, the transformation of carboxylic group of 1 into thiocarbamothioyl group at 3c, also observed from the loss of carboxylic acid absorption band at wave number of 2965-2559 $\mathrm{cm}^{-1}$, and change into absorption band at wave number of $3164\left(-\mathrm{N}-\mathrm{H}\right.$, amide, $\left.2^{\circ}\right)$ and $3037\left(-\mathrm{N}-\mathrm{H}\right.$, amine, $\left.2^{\circ}\right)$. This is also supported by NMR profile, ${ }^{1} \mathrm{H}-\mathrm{NMR}\left(400 \mathrm{MHz}, \mathrm{CDCl}_{3}\right)$ at $\delta_{\mathrm{H}}=9.65 \mathrm{ppm}(1 \mathrm{H}, \mathrm{s})$ for $-\mathrm{NHC}=\mathrm{O}$ and $12.41 \mathrm{ppm}$ $(1 \mathrm{H}, \mathrm{s})$ for $-\mathrm{NHC}=\mathrm{S}$. The $\mathrm{sp}^{2}$ carbon, $-\mathrm{C}=\mathrm{O}$ and $\mathrm{C}=\mathrm{S}$ was revealed by peak at $\delta_{\mathrm{C}}=166.06$ and 179.19 ppm respectively. In addition, both of the functional group absorb IR at wave number 1670 ($\mathrm{C}=\mathrm{O})$ and $1547(-\mathrm{C}=\mathrm{S}) \mathrm{cm}^{-1}$. The addition of four aromatic protons is shown by the presence of two symmetrical doublets at $7.51(2 \mathrm{H}, \mathrm{d}, \mathrm{J}=6.6 \mathrm{~Hz})$ and $6.91(2 \mathrm{H}, \mathrm{d}, J=6.6 \mathrm{~Hz})$ indicating the two pairs of protons having ortho positions. The second aromatic group was suggested by signals at chemical shift at $\delta_{H}=6.95(1 \mathrm{H}, \mathrm{dd}, J=2.4 \mathrm{~Hz}), 7.05$ $(1 \mathrm{H}, \mathrm{s}), 2.4 \mathrm{~Hz}), 7.29(1 \mathrm{H}, \mathrm{t}, \mathrm{J}=8 \mathrm{~Hz})$. Two methoxy group was showed by peak at $\delta \mathrm{H}=3.76(3 \mathrm{H}, \mathrm{s})$ and $3.81(3 \mathrm{H}, \mathrm{s}) \mathrm{ppm}$. Whereas the carbon indicated by ${ }^{13} \mathrm{CNMR}$ profile at $\delta \mathrm{c}=55.40$ (1C) and 55.60 (1C) ppm. Alkene proton clearly observed form peak at $6.64(1 \mathrm{H}, d, J=15.6 \mathrm{~Hz}), 7.77(1 \mathrm{H}, d, J=15.6)$, CNMR at $\delta c=112.81(1 \mathrm{C})$, and $146.42(1 \mathrm{C})$, as well as IR band absorption at wave number 1595($\mathrm{C}=\mathrm{C}-$, alkene). The molecular mass of $3 \mathrm{c}$ was confirmed by MS (ESI-HRMS) $[\mathrm{M}+\mathrm{Na}]^{+}: \mathrm{m} / \mathrm{z}(\%)=$ 365.0931 (100).

The spectroscopic data above revealed that three new compounds were successfully obtained, (E)-3-(3-methoxyphenyl)-N(phenylcarba-mobamothioyl)-acrylamide (3a); (E)-3-(3-methoxy phenyl)- $N$-(methylphenylcarbamothioyl)acrylamide (3b); (E)-3-(3methoxyphenyl)- $\mathrm{N}$-(methoxyphenyl carbamothioyl)acrylamide (3c).

Synthesis of 1 derivatives was following the reaction mechanism in Figure 2.

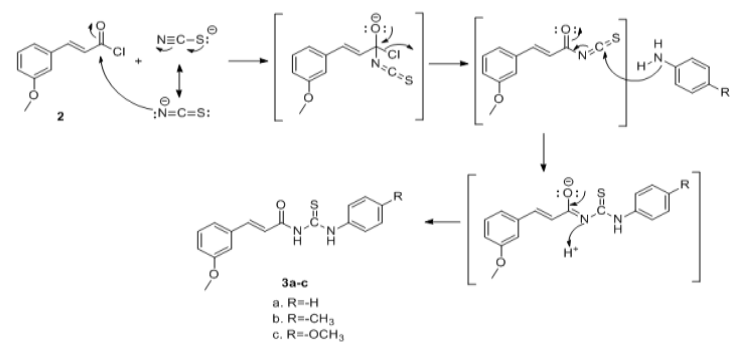

Figure 2 Reaction mechanism of synthesis 1 derivatives
The reaction mechanism of 1 modification, at Figure 2 indicated that the carboxylic acid group of 1 was first converted to acyl halide, i.e. $m$ methoxycinnamoyl chloride (2). Then ammonium thiocyanate attacked as nucleophile in addition reaction which catalyzed by PEG400 and using dichlorometane as solvent, resulting intermediate compound. The mechanism of PEG400 catalyst was by reducing the surface tension between ammonium thiocyanate as hydrophilic part and dichlorometane as lipophilic part through the formation of complexes around ammonium ion $\left(\mathrm{NH}_{4}\right)^{+}$[20]. The PEG400- $\mathrm{NH}_{4}{ }^{+} \mathrm{SCN}^{-}$complex form was attacked in a nucleophilic substitution reaction, by aromatic amines (ie aniline, $p$ toluidine and $p$-anisidine) as nucleophiles. From this study, three new compounds, $3 a, 3 b$, and $3 c$ were successfully obtained.

The use of microwave irradiation in chemical reaction will significantly reduce the reaction time. This is because the microwaves will make the polar molecules or ion to agitate and vibrate, which influenced by the magnetic field. The movement of the magnetic field trigger the particles to align with the field. The interaction of dipole moments from a material absorbs the electromagnetic energy, and then effectively convert it to heat (kinetic energy). Thus, the movement of particles is limited by the interactions in particles that produce heat at the center of the magnetic plate $[24,27]$.

\subsection{Physicochemical Properties}

The biological activity of a compound is influenced by its physicochemical property, the prediction of bioavailability and toxicity of the compound 3a-c was done by using online pKCSM program. The results of the in silico test along with the Rule of Five analysis from Lipinski are shown in Table 1.

Table 1 Analisis Lipinski Rule, Bioavaliability and Toxicity of compounds 3a-c

\begin{tabular}{|c|c|c|c|c|c|c|c|}
\hline Code & MW & $\log P$ & HBA & $\mathrm{HBD}$ & $\begin{array}{l}\text { Water sol. } \\
(\log \mathrm{mol} / \mathrm{L})\end{array}$ & $\begin{array}{c}\text { Intestinal } \\
\text { abs. (\%) }\end{array}$ & $\begin{array}{c}\text { Oral Rat } \\
\text { Acute } \\
\text { Toxicity } \\
\left(\mathrm{LD}_{50}\right) \\
\text { (mg/kg) }\end{array}$ \\
\hline $3 a$ & 312 & 3.52 & 3 & 2 & & & 645.5 \\
\hline $3 b$ & 326 & 4.00 & 3 & 2 & & & 705.8 \\
\hline $3 c$ & 342 & 3.39 & 3 & 2 & -4.291 & 92.191 & 776.0 \\
\hline \multicolumn{8}{|c|}{$\begin{array}{l}\text { MW = molecular weight } \\
\mathrm{HBA}=\text { hydrogen bonding acceptor } \\
\mathrm{HBD}=\text { hydrogen bonding donor } \\
\text { Bioavaliability and Toxicity predicted by using PKCSM on line } \\
\text { tool. }\end{array}$} \\
\hline
\end{tabular}

Table 1 showed that the molecular weight of $3 a-c$ (312-342) were less than 500. The value of the log partition coefficient in octanol/water (log P) 
was less than 5 (3.39-4.00). The amount of $\mathrm{HBD} \leq 5$ (3-5), number of HBA < 10 (3), indicating that all of the compound met the Five Rule of Lipinski requirements, so that the three compounds were predicted to be effective for oral use, easily absorbed and had high permeability [28]. Test compounds also have good intestinal absorption, $89.5-92.2 \%$. Its toxicity prediction > $500 \mathrm{mg} / \mathrm{kg}$ includes category 4 , low toxicity [29].

\subsection{Antiangiogenesis Assay}

Antiangiogenesis activity of compound $3 a-c$ was evaluated using a test model on chorioalantoic membrane vessels from embryonated chicken eggs. The chorio allantoic membrane is a membrane in egg, consist of chorion and allantoic, which formed after the $4^{\text {th }}$ day of incubation. These membranes have many blood vessels for vascularization and are most easily observed in line with the growth of chicken embryos [30]. The inducer used in this test is the basic Fibroblast Growth Factor (bFGF), a potent angiogenic factor and has activities related to the endothelial cell formation, proliferation and ultimately the formation of vascular tubes [31,32].

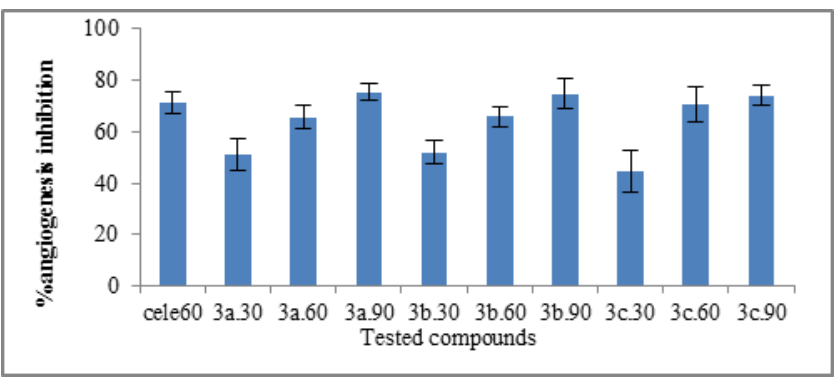

Figure 3 Effect treatment of cele $60 \mu \mathrm{g}$, compounds 3a$c$ on angiogenesis inhibition (\% average $\pm S D, n=5$ ) of compounds $3 \mathrm{a}-3 \mathrm{c}$ at dosage $30-90 \mu \mathrm{g}$

Notes: Cele60 is celecoxib at dose $60 \mu \mathrm{g} ; 3 \mathrm{a} .30$ is $3 \mathrm{a}$ at dose $30 \mu \mathrm{g} ; 3 \mathrm{a} .60$ is $3 \mathrm{a}$ at dose $60 \mu \mathrm{g} ; 3 \mathrm{a} .90$ is $3 \mathrm{a}$ at dose $90 \mu \mathrm{g} ; 3 \mathrm{~b} .30$ is $3 \mathrm{~b}$ at dose $30 \mu \mathrm{g} ; 3 \mathrm{~b} .60$ is $3 \mathrm{a}$ at dose $60 \mu \mathrm{g} ; 3 \mathrm{~b} .90$ is $3 \mathrm{a}$ at dose $90 \mu \mathrm{g} ; 3 \mathrm{c} .30$ is $3 \mathrm{c}$ at dose $30 \mu \mathrm{g} ; 3 \mathrm{c} .60$ is $3 \mathrm{c}$ at dose $60 \mu \mathrm{g} ; 3 \mathrm{c} .90$ is $3 c$ at dose $90 \mu \mathrm{g}$.

The results of angiogenesis inhibition test were expressed by inhibition of formation of new vascular endothelial cells (Figure 3). Percentage inhibition of each sample i.e. $(71 \pm 4.4) \%,(51 \pm 6.3) \%$, $(66 \pm 4.8) \%, \quad(75 \pm 3.3) \%, \quad(52 \pm 4.5) \%, \quad(66 \pm 3.8) \%$ ， $(75 \pm 6.1) \%, \quad(45 \pm 8.0) \%, \quad(71 \pm 7.0) \%, \quad(74 \pm 3.8) \%$, for cele60, 3a.30, 3a.60, 3a.90, 3b.30, 3b.60, 3b.90, $3 c .30,3 c .60,3 c .90$, respectively.

Microscopically, a new blood vessel is defined as the blood vessel that grows and develops from the main blood vessels having a round or oval lumen. Its wall is like a thin membrane and homogenous, and not yet bound to other muscles. This vessel rarely has a few endothelial nucleus, and the lumen does not contain blood cells [33-35]. In this study, the observed was the new blood vessels formed around the lumen of the main blood vessel.

Based on the one-way variant analysis (oneway ANOVA), there was a significant difference in the number of endothelial cells between the negative control group (bFGF) and the treatment groups (bFGF + test compounds) (sig. 0.00). This revealed that the tested compound, starting at $30 \mu \mathrm{g}$, showed a significant angiogenesis inhibition. For each tested compound ( $3 a, 3 b$ and $3 c$ ), there were significant differences between the doses of 30,60 and $90 \mu \mathrm{g}$ (sig. 0.00), which showed that the activity was dose dependent. When compared to the same dose, there were no significant differences between compounds $3 a, 3 b$ and $3 c$ (p> 0.05). This indicated that the presence of substituents in the ring aromatic amine did not affect the activity. This was presumably because the three tested compounds had similar physicochemical properties (Table 1), and high permeability, so that all of them easily penetrate the capillary blood vessel membrane and provide similar potential effects.

Compared to the positive control of celecoxib (cele) $60 \mu \mathrm{g}$, the tested compound at dose 60 and $90 \mu \mathrm{g}$ showed no significant difference $(p>0.05)$. Based on this, it was predicted that the mechanism of action of compound $3 a-c$ also works to inhibit COX-2 during the bFGF induction process. In the treatment groups, the number of new vascularization of blood vessels were less than the negative control. This reinforces the notion that the tested compounds also inhibits vascular endothelial growth factor (VEGF).

The presence of COX-2 is also strongly expressed in the neoplastic cells, consist of metastatic nodes. Thus, a large number of COX-2 is found in angiogenic vascularization that occurs in rheumatoid arthritis, primary tumors, and metastatic disease. Reduce of prostaglandin levels from the inhibition of COX-2 activity result in angiogenesis. It is expected that the COX-2 inhibition from prostaglandin will have a direct inhibitory effect on the in vivo angiogenesis [35].

In vivo experiments using CAM (Chorioallatoic Membrane) showed that the inhibition of COX-2 expression resulted in angiogenesis inhibiton, which was preceded by a decrease in bFGF expression. Therefore, the administration of NSAIDs including celecoxib as anti-inflammatory also acts as an anti-angiogenesis [34]. Similarly, COX-2 inhibition from prostaglandin can inhibit the production of growth factors including VEGF. The development of several selective COX-2 inhibitors of anti-angiogenesis as well as tyrosine kinase inhibitors enabling simultant inhibition of EGFR and VEGF pathways $[36,37]$. 
Figure 4 revealed that the endothelial cells composing capillaries (arrows) in the mesenchymal tissue of the CAM of the bFGF treatment group (Figure 4A) are very good (arrow). The young endothelial cell nucleus is prominent in the capillary lumen. There appears the inhibition of endothelial cell growth due to the treatment of the compound $3 \mathrm{c}$ dose $60 \mu \mathrm{g}$ (Figure

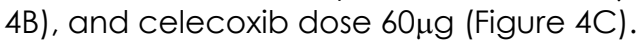

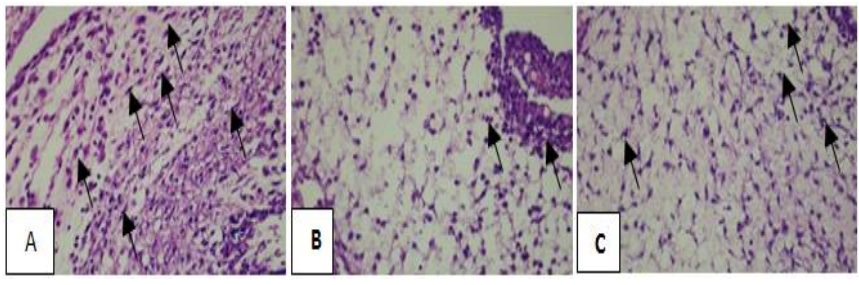

Figure 4 Examples of endothelial cell of chorio allantoic histological images for the bFGF treatment group (A), $\mathrm{bFGF}+3 \mathrm{a} 60 \mu \mathrm{g}(\mathrm{B})$, and $\mathrm{bFGF}+$ Celecoxib $60 \mu \mathrm{g}$ (C) (HE; 400x; mikroskop Nikon H600L; camera DS Fi2 300 megapixel).

\subsection{Molecular Docking Study}

To find out the inhibition mechanism, in silico studies using EGFR kinase (PDB:1XKK) and COX-2 (PDB: 1CX2) were carried out. The results of the in silico of 1 derivates on the EGFR kinase and COX-2 were shown in Table 2. The interactions of each $1,3 a-c$ in the active site of EGFR kinase and COX-2 are shown in Figure 5 and Figure 6, respectively.

Table 2 Rerank Score (RS) on PDB: 1XKK and PDB: 1CX2

\begin{tabular}{ccc}
\hline Compds & RS (kcal/mol) & RS (kcal/mol) \\
& PDB 1XKK & PDB 1CX2 \\
\hline $\mathbf{1}$ & -81.728 & -72.849 \\
3a & -106.331 & -116.839 \\
3b & -108.328 & -126.044 \\
3c & -109.645 & -130.100 \\
cele & -97.308 & -125.260 \\
\hline
\end{tabular}

Table 2, showed that the modification of the structure of compound 1 to $3 a-c$ increases its interaction with EGFR kinase, and COX-2. Kuwano et al., (2004) revealed that celecoxib is a COX-2 inhibitor [3]. This research found that the RS value of celecoxib interaction with COX-2 (PDB 1CX2) was lower than EGFR kinase (PDB 1XKK), suggesting that the inhibition of celecoxib to COX2 was stronger than EGFR kinase. Celecoxib interacted with EGFR kinase at residue Leu792, Leu844, Val726, Asn842, Leu788 (Figure 5a). While interaction of celecoxib with COX-2 occurred at Met522, Arg120, Tyr355, Val349, Val523, Phe518, Arg513, His90, Ser530 (Figure 6a).

The RS value of the interaction between compound 1 and EGFR kinase (PDB 1XKK) was lower than COX-2 (PDB 1CX2). It can be predicted that the potency of compound 1 is more stable to interact with COX-2 than EGFR kinase.

Interaction of compounds $3 a-c$ with EGFR kinase were more stable than 1 and cele, marked by the lower RS value. The addition of aromatic and thiocarbamothioyl moieties significantly changed their interaction, because there are more hydrophobic and hydrogen bonding interaction with residue amino acids of EGFR kinase. Compounds 3a-c have same interaction at Thr854, Lys745 and Leu788. However, addition interaction of the methyl moiety of $3 b$ and methoxy moiety of $3 c$ did not significantly affect their RS with this target molecule (Figure 5c-e). Strong interactions are expected to reduce VEGF expression which stimulates angiogenesis [33,34].

The addition of one amine aromatic ring thiourea derivatives increased its interaction at the active side of COX-2. On all of compounds $3 a-c, N$ atom interacts as hydrogen bonding acceptor with residue Gly526. All thiourea moieties of $3 a-c$ have hydrophobic interaction with residues Ser530, Tyr385, and Leu352. Among of three derivatives tested, compound $3 c$ also has the most stable interaction with COX-2, marked by the lowest RS value (Figure 6c-e).

The potential for inhibition of COX-2 and VEGF expression requires further immunohistochemistry research.
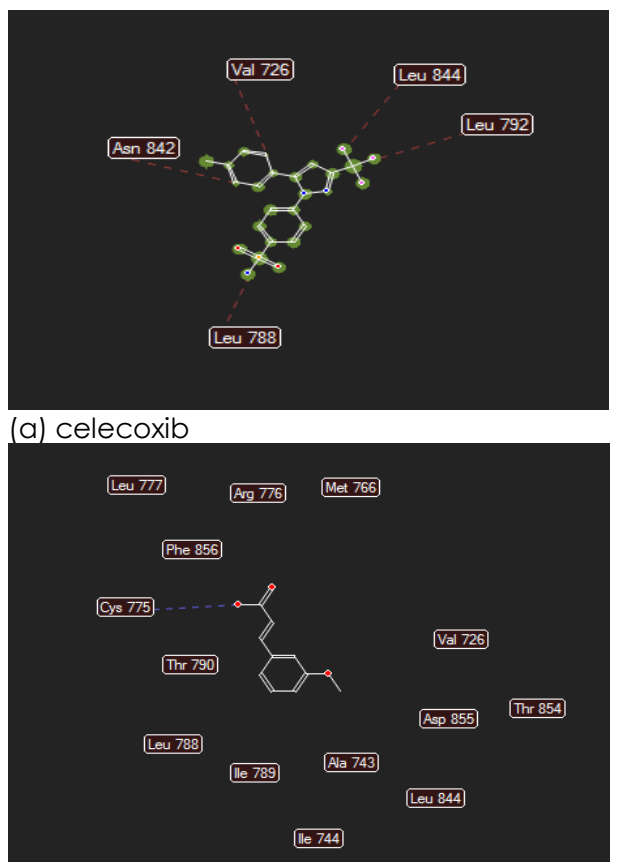

(b) 1 

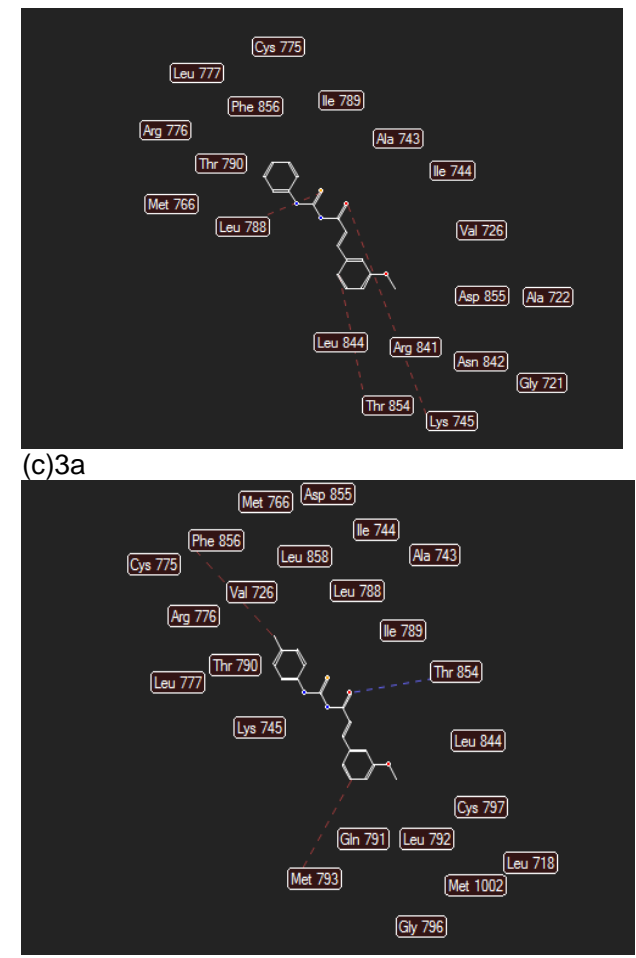

\section{(d) $3 b$}

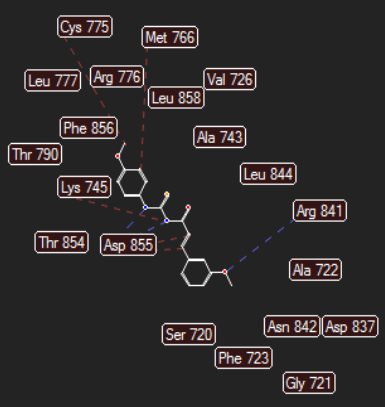

(e)3c

Figure 5 2D molecular interaction of celecoxib (a), 1 (b), $3 a-c(c-e)$ with amino acid residues at active site of EGFR kinase (PDB 1XKK). Cavity 1 vol.215.04

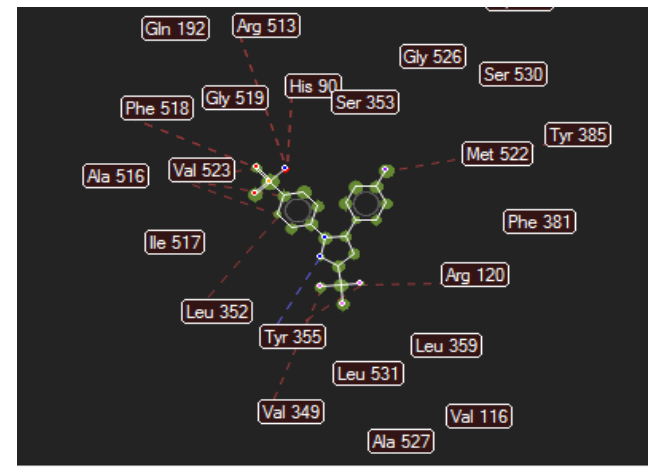

(a)celecoxib

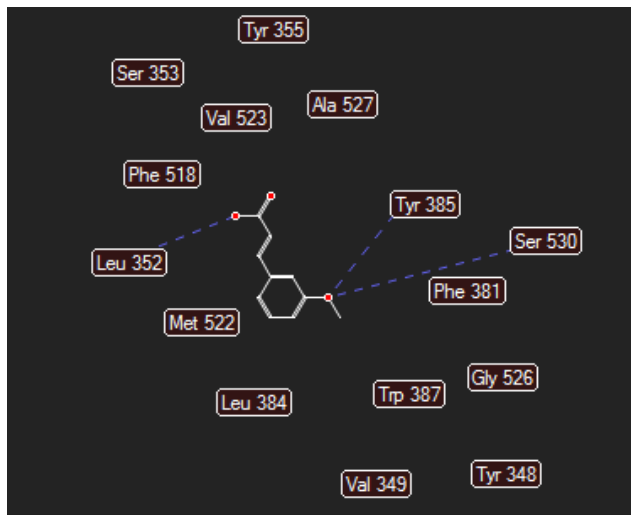

(b) 1

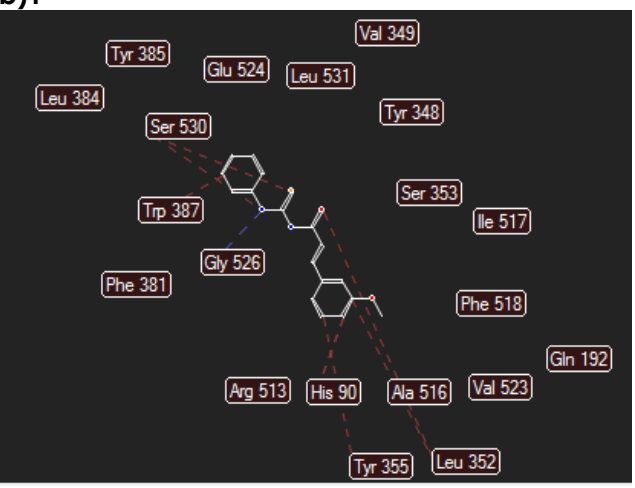

(c) $3 a$

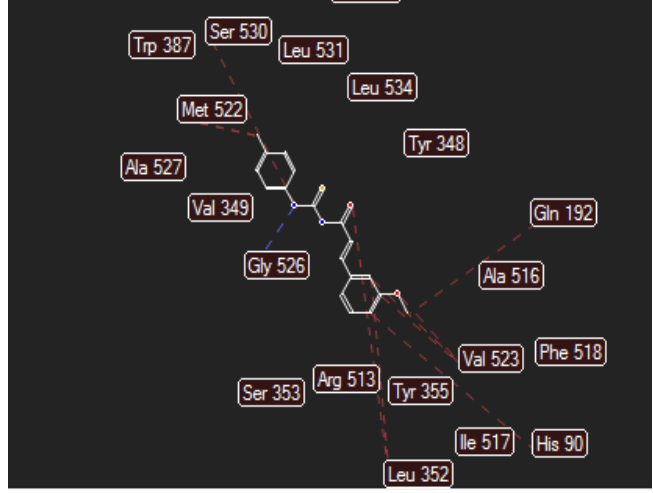

(d)3b

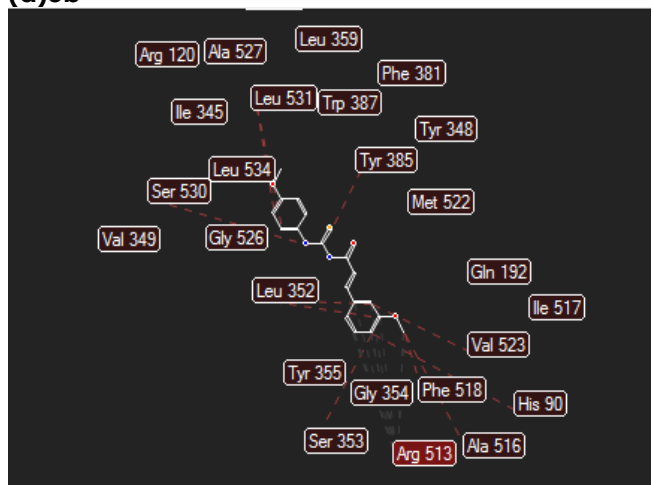

(e)3c

Figure 6 2D molecular interaction of celecoxib (a), 1 (b), $3 a-c$ (c-e) with amino acid residues at active site of COX-2 (PDB 1CX2). COX-2 in cavity 3 vol 139.776 


\subsection{CONCLUSION}

In this study, it was concluded that three new thiourea derivatives (3a-c) successfully synthesized through microwave irradiation. All of the compounds had anti-angiogenic activity tested with CAM models.

\section{Acknowledgement}

The authors acknowledged to Airlangga University for financial support through Penelitian Unggulan Fakultas (PUF) Grant in year 2018.

\section{References}

[1] Sahib, H. B., Al-Zubaidy, A. A., Jasim, G. A. 2016. Anti Angiogenic Activity Of Vitex Agnus Castus Methanol Extract In Vivo Study. Iran J Pharm Sci. 12(1): 59-68.

[2] Xu. L., Croix, B. St. 2014. Improving VEGF-targeted Therapies through Inhibition of COX-2/PGE 2 Signaling. $\mathrm{Mol}$ Cell Oncol [Internet]. 1(4): e969154. Available from:

http://www.tandfonline.com/doi/full/10.4161/2372354 8.2014.969154.

[3] Kuwano, T., Nakao, S., Yamamoto, H., Tsuneyoshi, M., Yamamoto, T., Kuwano, M., et al. 2004. Cyclooxygenase 2 is a Key Enzyme for Inflammatory Cytokine-induced Angiogenesis. FASEB J [Internet]. 18(2): $300-10 . \quad$ Available from: http://www.ncbi.nlm.nih.gov/pubmed/14769824.

[4] Hsu, H. H., Lin, Y. M., Shen, C. Y., Shibu, M. A., Li, S. Y., Chang, S. H., et al. 2017. Prostaglandin E2-induced COX-2 Expressions via EP2 and EP4 Signaling Pathways in Human LoVo Colon Cancer Cells. Int J Mol Sci. $18(6)$.

[5] Xin, X., Majumder, M., Girish, G. V., Mohindra, V., Maruyama, T., Lala, P. K. 2012. Targeting COX-2 and EP4 to Control Tumor Growth, Angiogenesis, Lymphangiogenesis and Metastasis to the Lungs and Lymph Nodes in a Breast Cancer Model. Lab Investig [Internet]. 92(8): 1115-28.

Available: $\mathrm{http}: / /$ dx.doi.org/10.1038/labinvest.2012.90.

[6] Abraham Sunshine NYEMLL, Carole, E. siege, Mamaroneck all of NY, [73]. United States Patent 191. 1985:4,552,899.

[7] Evans, T. C., Gavrilovich, E., Mihai, R. C. and Isbasescu, I. EL, Thelen, D., Martin, J. A., Allen, S. M., S. A. S. (12) Patent Application Publication (10) Pub. No.: US 2006/0222585 A1 Figure 1. (2017); 002(15),354.

[8] Newton, H. B. 2009. Bevacizumab: Review of Development, Pharmacology, and Application to Brain Tumors. Clin Med Ther. 1: 1577-97.

[9] Jana, D., Sarkar, D. K., Ganguly, S., Saha, S., Sa, G., Manna, A. K., et al. 2014. Role of Cyclooxygenase 2 (COX-2) in Prognosis of Breast Cancer. Indian J Surg Oncol. 5(1): 59-65.

[10] Grünewald, F. S., Prota, A. E., Giese, A., Ballmer-Hofer, K. 2010. Structure-function Analysis of VEGF Receptor Activation and the Role of Coreceptors in Angiogenic Signaling. Biochim Biophys Acta-Proteins Proteomics [Internet]. 1804(3): 567-80. Available from: http://dx.doi.org/10.1016/j.bbapap.2009.09.002.

[11] Sun, S., Zhang, J., Wang, N., Kong, X., Fu, F., Wang, H. et al. 2017. Design and Discovery of Quinazoline- and Thiourea-Containing Sorafenib Analogs as EGFR and VEGFR-2 Dual TK Inhibitors. Molecules [Internet]. 23(1):
24. Available from: http://www.mdpi.com/1420$3049 / 23 / 1 / 24$.

[12] Kumar, B. N. P., Rajput, S., Dey, K. K., Parekh, A., Das, S., Mazumdar, A., et al. 2013 Celecoxib Alleviates Tamoxifen-instigated Angiogenic Effects by ROSdependent VEGF/VEGFR2 Autocrine Signaling. BMC Cancer [Internet]. 13(1): 273. Available from: http://bmccancer.biomedcentral.com/articles/10.118 6/ 1471-2407-13-273.

[13] Wu, G. F., Luo, J., Rana, J. S., Laham, R., Sellke, F. W., Li, J. 2006. Involvement of COX-2 in VEGF-induced Angiogenesis via P38 and JNK Pathways in Vascular Endothelial Cells. Cardiovasc Res. 69(2): 512-9.

[14] Ekowati, J., Hardjono, S., Hamid, I. S. 2015. Ethyl pmethoxycinnamate from Kaempferia Galanga Inhibits Angiogenesis Through Tyrosine Kinase. Universa Med. 34(1): 43-51.

[15] Umar, M. I., Asmawi, M. Z., Sadikun, A., Atangwho, I. J., Yam, M. F., Altaf, R., et al. 2012. Bioactivity-guided Isolation of Ethyl-p-methoxycinnamate, An AntiInflammatory Constituent, from Kaempferia Galanga L. Extracts. Molecules. 17(7): 8720-34.

[16] Sulistyowaty, M. I., Nugroho, A. E., Putra, G. S., Ekowati, J., Budiati, T. 2016. Syntheses, Molecular Docking Study and Anticancer Activity Examination of $P$ Methoxycinnamoyl Hydrazides. Int J Pharm Clin Res. 8(6): 623-627.

[17] Manoharan, S., Rejitharaji, T., Prabhakar, M. M. Manimaran, A., Singh, R. B. 2014. Modulating Effect of Ferulic Acid on NF-KB COX-2 and VEGF Expression Pattern During 7, 12-Dimethylbenz(a)anthracene Induced Oral Carcinogenesis. Open Nutraceuticals J. 7(2007): 33-8.

[18] Peng, C. C., Chyau, C. C., Wang, H. E., Chang, C. H., Chen, K. C., Chou, K. Y., et al. 2013. Cytotoxicity of Ferulic Acid on T24 Cell Line Differentiated by Different Microenvironments. Biomed Res Int. Article ID 579859.

[19] Gunasekaran, S., Venkatachalam, K., Namasivayam, N. 2018. Anti-inflammatory and Anticancer Effects of p-methoxycinnamic Acid, an Active Phenylpropanoid, against 1,2-dimethylhydrazine-induced Rat Colon Carcinogenesis. Mol Cell Biochem [Internet]. 0(0): 1-13. Available from: http://dx.doi.org/10.1007/s11010-0183398-5.

[20] Ekowati, J., Tejo, B. A., Sasaki, S., Highasiyama, K., Sukardiman, Siswandono, et al. 2012. Structure Modification of Ethyl p-methoxycinnamate and their Bioassay as Chemopreventive Agent against Mice's Fibrosarcoma. Int J Pharm Pharm Sci. 4(SUPPL. 3): 528532.

[21] Shoaib, M., Shafiullah, Ayaz, M., Tahir, M. N., Shah, S. W. A. 2016. Synthesis, Characterization, Crystal Structures, Analgesic and Antioxidant Activities of Thiourea Derivatives. J Chem Soc Pakistan. 38(3): 479486.

[22] Ghorab, M. M., El-Gaby, M. S. A., Alsaid, M. S., Elshaier, Y. A. M. M., Soliman, A. M., El-Senduny, F. F., et al. 2017. Novel Thiourea Derivatives Bearing Sulfonamide Moiety as Anticancer Agents Through COX-2 Inhibition. Anticancer Agents Med Chem [Internet]. 17(10): 1411-1425. Available from: http://www.eurekaselect.com/151128/article.

[23] van Schijndel, J., Canalle, L. A., Molendijk, D., Meuldijk, J. 2017. The Green Knoevenagel Condensation: Solvent-free Condensation of Benzaldehydes. Green Chem Lett Rev. 10(4): 404-11.

[24] Lipinski, C. A. 2016. Rule of Five in 2015 and Beyond: Target and Ligand Structural Limitations, Ligand Chemistry Structure and Drug Discovery Project Decisions. Adv Drug Deliv Rev [Internet]. 101: 34-41. Available http://dx.doi.org/10.1016/j.addr.2016.04.029. 
[25] Prabhu, K., Mahto, M. K., Gopalakrishnan, V. K. 2014. Virtual Screening, Molecular Docking and Molecular Dynamics Studies for Discovery of Novel Vegfr-2 Inhibitors. International Journal of Pharmaceutical and Clinical Research. 6(3): 221-229.

[26] Coskun, G. I. P., Djikic, T., Hayal, T. B., Turkel, N., Yelekçi, K., Sahin, F., and Küçükgüzel, S. G. 2018. Synthesis, Molecular Docking and Anticancer Activity of Diflunisal Derivatives as Cyclooxygenase Enzyme Inhibitors. Molecule. 23(1969): 1-19. doi:10.3390/molecules23081969.

[27] Pineiro, M., Dias, L., Damas, L., Aquino, G., Calvete, M. and Pereira, M. 2016. Microwave Irradiation as a Sustainable Tool for Catalytic Carbonylation Reactions. Inorganica Chimica Acta. 455: 364-377.

[28] Pires, D. E. V., Blundell, T. L., Ascher, D. B. 2015. pkCSM Predicting Small-molecule Pharmacokinetic and Toxicity Properties Using Graph-based Signatures. J Med Chem. 58(9): 4066-72.

[29] Ribatti, D. 2010. The Chick Embryo Chorioallantoic Membrane as an In Vivo Assay to Study Antiangiogenesis. Pharmaceuticals. 3(3): 482-513.

[30] Salcedo, R., Zhang, X., Young, H. A., Michael, N., Wasserman, K., Ma, W. H., et al. 2003. Angiogenic Effects of Prostaglandin E2are Mediated by upregulation of CXCR4 on Human Microvascular Endothelial Cells. Blood. 102(6): 1966-77.

[31] Majima, M., Hayashi, I., Muramatsu, M., Katada, J., Yamashina, S., Katori, M. 2000. Cyclo-oxygenase-2 Enhances Basic Fibroblast Growth Factor-induced Angiogenesis through Induction of Vascular Endothelial Growth Factor in Rat Sponge Implants. Br J Pharmacol. 130(3): 641-9.

[32] Cheng, H-W., Chen, Y-F., Wong, J-M., Weng, C-W., Chen, H-Y., Yu, S-L., et al. 2017. Cancer Cells Increase
Endothelial Cell Tube Formation and Survival by Activating the PI3K/Akt Signalling Pathway. J Exp Clin Cancer Res [Internet]. 36(1): 27. Available from: http://jeccr.biomedcentral.com/articles/10.1186/s130 46-017-0495-3.

[33] Burri, P. H., Hlushchuk, R., Djonov, V. 2004. Intussusceptive Angiogenesis: Its Emergence, Its Characteristics, and Its Significance. Dev Dyn. 231 (3): 474-88.

[34] Niu, G., Chen, X. 2010. Vascular Endothelial Growth Factor as an Anti-angiogenic Target for Cancer therapy. Curr Drug Targets [Internet]. 11 (8): 1000-17. Available from: http://www.pubmedcentral.nih.gov/articlerender.fcgi ? artid $=3617502 \&$ tool=pmcentrez\&rendertype=abstrac $\dagger$

[35] Leahy, K., Koki, A., Masferrer, J. 2000. Role of Cyclooxygenases in Angiogenesis. Curr Med Chem [Internet]. 7(11): 1163-70. Available from: http://www.eurekaselect.com/openurl/content.php? genre $=$ article\&issn $=0929$ 8673\&volume $=7$ \&issue $=11$ \&spage $=1163$.

[36] Valverde, A., Peñarando, J., Cañas, A., LópezSánchez, L. M., Conde, F., Hernández, V., et al. 2015. Simultaneous Inhibition of EGFR/VEGFR and Cyclooxygenase-2 Targets Stemness-related Pathways in Colorectal Cancer Cells. PLoS One [Internet]. 10(6): 1-23. Available from: http://dx.doi.org/10.1371/journal.pone.0131363.

[37] Tabernero, J. 2007. The Role of VEGF and EGFR Inhibition: Implications for Combining Anti-VEGF and Anti-EGFR Agents. Mol Cancer Res [Internet]. 5(3): 20320. Available from: http://mcr.aacrjournals.org/cgi/doi/10.1158/15417786.MCR-06-0404. 